\title{
Public Participation in China's Water Governance
}

\author{
Otto SPIJKERS \\ University Lecturer, Utrecht University, Utrecht Centre for Water, Oceans \\ and Sustainability Law, the Netherlands \\ o.spijkers@uu.nl
}

Xian LI

Graduate student, Utrecht University, Utrecht, the Netherlands

lixian68@foxmail.com

\begin{abstract}
Liping DAI
Postdoctoral researcher, Utrecht University, Utrecht Centre for Water, Oceans and Sustainability Law, the Netherlands

l.dai@uu.nl
\end{abstract}

\begin{abstract}
This article analyses the role of public participation in China's water governance. First, it provides an overview of the relevant international law provisions applicable to China. This is followed by an analysis of the implementation of these international obligations and their incorporation into China's domestic water governance. The article demonstrates that the problem is not a lack of rules and regulations calling for public participation, but rather that these rules and regulations are often too vague to be meaningfully applied in practice. It is not always clear what type of public participation is called for, and which public should be invited to participate.
\end{abstract}

\section{Keywords}

international water law - freshwater governance - public participation rights - China 
Many individuals, both within and outside China, are affected in one way or another by China's governance of its freshwater resources, such as rivers, lakes, confined and non-confined groundwaters. This raises the question whether these individuals are-or should be-entitled to take part in China's water governance and, if so, in what way?

We delineate the scope of our analysis in various ways. First, the article focuses on one important element of water governance, namely the role of 'the public.' Second, it confines its examination to China. ${ }^{2}$ Third, we only look at public participation in water governance as far as it relates to the protection of the environment. We have not analysed the role of the public in decision making relating to other water governance issues, such as equitable water quantity allocation.

Our research question is: what is the role and current status of public participation in China's water governance? We analyse this question in a number of stages. First, we look at the more general question of what the role of the public ought to be according to the relevant international treaties to which China is a party. Then we look at how these international commitments have been translated into domestic policies. ${ }^{3}$ Finally, we look at the part played by public participation in China's water governance according to China's own domestic legal system.

Before we address the main research question, we first need to make clear what we mean by water governance. There exist many definitions and descriptions of governance, water governance and international water governance. ${ }^{4}$ Water governance has for instance been defined as:

1 Karin M KRCHNAK, 'Improving Water Governance Through Increased Public Access to Information and Participation' (2005) 5 Sustainable Development Law and Policy 34-39; Jona RAZZAQUE, 'Public Participation in Water Governance' in Joseph W DELLAPENNA and Joyeeta GUPTA (eds), The Evolution of the Law and Politics of Water (Springer 2009).

2 On the issue of public participation in water resources management in general, see Mara TIGNINO and Komlan SANGBANA (eds), Public Participation and Water Resources Management: Where Do We Stand in International Law? (UNESCO 2015) <http://www.unige .ch/droit/eau/index.php/download_file/view/202/689/> accessed 23 April 2018.

3 We did not look at how these domestic policies were actually implemented on the ground. That would have required an entirely different kind of research study and would have taken us beyond the desk research upon which this article is based.

4 There is a large body of literature on the concept of 'water governance'. See e.g. Alistair RIEUCLARKE and Patricia WOUTERS, 'The Role of International Water Law in Ensuring "Good Water Governance”: a Call for Renewed Focus and Action' (2004) 15(3) The Journal of Water 
The range of formal and informal political, social, economic, and administrative systems that are in place to develop and manage water resources, and the delivery of water services, at different levels of society. ${ }^{5}$

Transboundary governance, the focus of the first part of this article, has been described as:

A formal or informal framework to manage a natural resource or to address an environmental problem shared between two or more jurisdictions. ${ }^{6}$

Taken together, these definitions give us a good first grasp of what international water governance is about. Briefly put, we take international water governance to refer to formal and informal systems that are put in place to develop and manage freshwater resources that are shared between two or more jurisdictions.

We then need to define public participation. ${ }^{7}$ Public participation has been described as 'a process by which the views and concerns of the public are identified and incorporated into decision making by public institutions.' ${ }^{8}$ Of course, this is not the only definition of public participation that is offered in scholarship. As with water governance, there are many definitions. ${ }^{9}$ They

Law 89; Olcay UNVER, 'Global Governance of Water: A Practitioner's Perspective' (2008) 14(4) Global Governance 409; Patricia WOUTERS, 'Global Water Governance through Many Lenses' (2008) 14(4) Global Governance 523; Andrea K GERLAK, Robert G VARADY and Arin C HAVERLAND, 'Hydrosolidarity and International Water Governance' (2009) 14(2) International Negotiation 311; Susanne SCHMEIER, Governing International Watercourses: River Basin Organizations and the Sustainable Governance of Internationally Shared Rivers and Lakes (Routledge 2012); Joseph W DELLAPENNA, 'Thinking about the Future of Global Water Governance' in Laura WESTRA, Prue TAYLOR and Agnès MICHELOT (eds), Confronting Ecological and Economic Collapse: Ecological Integrity for Law, Policy and Human Rights (Earthscan 2013); Joyeeta GUPTA, 'Global Water Governance' in Robert FALKNER (ed), The Handbook of Global Climate and Environment Policy (Wiley-Blackwell 2013).

5 Richard SAUNIER and Richard MEGANCK, Dictionary and Introduction to Global Environmental Governance (Talyor and Francis 2012) 297.

6 Ibid 234.

7 See Otto SPIJKERS and Arron HONNIBALL, 'Developing Global Public Participation (1)' (2015) 17(3) International Community Law Review 222.

8 SAUNIER and MEGANCK $\left(\mathrm{n}_{5}\right) 269$.

9 See e.g. Gene ROWE and Lynn J FREWER, 'Evaluating Public-Participation Exercises: A Research Agenda' (2004) 29(4) Science, Technology, \& Human Values 512, 512 and 521; Rajendra RAMLOGAN, Sustainable Development: Towards A Judicial Interpretation (Martinus Nijhoff 2010) 163; Kathleen BOTTRIELL and Marie-Claire CORDONIER SEGGER, 'The Principle of Public Participation and Access to Information and Justice' (Centre for International 
all derive from a common idea, namely that institutions should allow people with an interest in a decision-making process to be involved in some way in that process. Public participation is oftentimes perceived as a way to empower people who are otherwise ignored in public policymaking. This aspect of 'empowerment' is to be found in many definitions, including the highly influential definition of 'citizen participation' developed by Sherry ARNSTEIN. ${ }^{10}$ She described citizen participation as 'a categorical term for citizen power.'11 In her view, 'it is the redistribution of power that enables the have-not citizens, presently excluded from the political and economic processes, to be deliberately included in the future.'12 Our approach to public participation is somewhat more neutral and less focused on empowerment. We thus include participation by powerful players-large corporations for example - in our definition of public participation.

In this article, we look at the role of public participation in China's systems put in place to manage its transboundary freshwater resources. Our purpose is not to describe or study these governance systems per se, but to focus on international and domestic legislation that obliges China to create particular opportunities for public participation. It is on that legislation and its implementation in practice that our analysis focuses. To do so, we first provide an overview of international law provisions specifically relating to public participation that are binding on China and look at how China has incorporated these international obligations into its own water governance (section 2). We then look at the role of public participation in Chinese domestic water governance in a more general sense (section 3 ) and draw some conclusions (section 4).

\section{$2 \quad$ Public Participation in International Water Law as Applicable to China}

\subsection{Introduction}

This section begins with a review of the treaties to which China is a party that are relevant to water governance and that include provisions calling on States to facilitate public participation in decision-making processes. We then

Sustainable Development Law, Recent Developments in International Law Related to Sustainable Development Working Paper 2005) 3.

10 Sherry ARNSTEIN, 'A Ladder of Citizen Participation' (1969) 35(4) Journal of the American Planning Association 216.

11 Ibid.

12 Ibid. 
examine the implementation of these treaty obligations in China as revealed in public documents and literature.

With regard to our methodology and selection of sources, we have identified three different categories of treaties relevant to water governance (see Table 1$) \cdot{ }^{13}$

TABLE 1 Relevant treaties

\section{Category of treaties Examples}

Treaties specifically regulating the exploitation of freshwater resources

Border treaties, which contain references to the sustainable exploitation of a watercourse which determines a border
2008 Sino-Russia Agreement on Reasonable

Utilisation and Protection of Transboundary Waters

2011 Sino-Kazakhstan Agreement on Protection of Water Quality on Transboundary Rivers 2001 Sino-Kazakhstan Cooperation Agreement on the Utilisation and Protection of Transboundary Rivers

1994 Sino-Mongolia Agreement on Protection and Utilisation of Border Waters

2006 Agreement on the Management System of the China-Russia Border 1988 Sino-Mongolia Treaty on Common Boundaries and Settlement of Boundary Matters 2006 Agreement on the Management System of the China-Kazakhstan Border 2009 Sino-Vietnam Land Border Management System Agreement

13 The treaties listed in Table 1 were identified from a search of several comprehensive and authoritative databases available to the public, including the UN Treaty Collection $<$ https://treaties.un.org >, the website of the Chinese Ministry of Foreign Affairs $<\mathrm{http}: / /$ www.fmprc.gov.cn>, and the Global Law database maintained by the Chinese Ministry of Commerce. 
TABLE $1 \quad$ Relevant treaties (cont.)

\section{Category of treaties}

Treaties addressing other environmental matters, which have a direct or indirect bearing on their exploitation
Examples

1998 'Rotterdam' Convention on the Prior Informed Consent Procedure for Certain Hazardous Chemicals and Pesticides in International Trade 1992 Convention on Biological Diversity 2000 Cartagena Protocol on Biosafety to the Convention on Biological Diversity 1992 United Nations Framework Convention on Climate Change 2001 Stockholm Convention on Persistent Organic Pollutants 1994 United Nations Convention to Combat Desertification 2008 Environmental Cooperation Agreement between New Zealand and China 2004 Sino-France Agreement concerning the Promotion of a Clean Development Mechanism

Looking at the three categories of treaties mentioned in Table 1, we focus on provisions relating to public participation. This includes bilateral as well as multilateral treaties, among which are treaties referring to the management of a particular watercourse or to the management of freshwater resources in a general sense. ${ }^{14}$ Most of the provisions on public participation referred to in this section are not to be found in water law treaties but in environmental law treaties which indirectly relate to water governance.

There is a limited number of treaties with provisions on public participation to which China is a party. It is not the aim of this article to speculate on the political reasons for this. However, it could be argued that a pledge to facilitate public participation, made at the international level, automatically entails a

14 For a more general discussion of how these treaties promote the sustainable utilization of China's watercourses, see Otto SPIJKERS, Xian LI and Liping DAI, 'Sustainable Development in China's International and Domestic Water Law' (2015) 24(5-6) Journal of Water Law 207. 
limitation of the State's national sovereignty and autonomy to make its own policies and that China is perhaps reluctant to limit its sovereignty in this way. The doctrine of sovereignty creates barriers to intrusions into domestic affairs. ${ }^{15}$ It must be recalled that China is not a party to the UN Convention on the Law of the Non-Navigational Uses of International Watercourses (the UN Watercourses Convention). ${ }^{16}$ Likewise, it is not a party to the Convention on the Protection and Use of Transboundary Watercourses and International Lakes. ${ }^{17}$ It is difficult to argue that the rather progressive provisions on public participation in the latter Convention have already crystallized into customary international law so as to be binding on China as custom. Therefore, these treaties are not included in the scope of our study.

This brings us to the question of customary obligations more generally. Is there a customary norm on public participation? Principle 10 of the Rio Declaration on Environment and Development, adopted at the United Nations Conference on Environment and Development in Rio de Janeiro in June 1992, proclaims a principle of public participation:

Environmental issues are best handled with participation of all concerned citizens, at the relevant level. At the national level, each individual shall have appropriate access to information concerning the environment that is held by public authorities, including information on hazardous materials and activities in their communities, and the opportunity to participate in decision-making processes. States shall facilitate and encourage public awareness and participation by making information widely available. Effective access to judicial and administrative proceedings, including redress and remedy, shall be provided. ${ }^{18}$

The Rio Declaration is itself not a legally binding document. This principle has nonetheless had such an impact on the drafting of agreements in the field of environmental law that one could argue that it is has become binding as

15 See Karl LOEWENSTEIN, 'Sovereignty and International Co-operation' (1954) 48(2) The American Journal of International Law 224; and Kal RAUSTIALA, 'States, NGOs, and International Environmental Institutions' (1997) 41(4) International Studies Quarterly 728 .

16 Convention on the Law of the Non-Navigational Uses of International Watercourses, in Annex of UN General Assembly resolution 51/229 (21 May 1997) ('UN Watercourses Convention').

17 Convention on the Protection and Use of Transboundary Watercourses and International Lakes (17 March 1992) 1936 UnTS 269.

18 Principle 10, Rio Declaration on Environment and Development (14 June 1992) A/CONF $.151 / 26$ (Vol. I). 
custom. Before the Rio Declaration was proclaimed, very few environmental agreements referred to public participation. After 1992, almost all such agreements did. ${ }^{19}$ The UN Watercourses Convention is one of the exceptions to this rule. When examining the treaties below, we thus need to keep the principle of public participation contained in the Rio Declaration in mind, as it could be argued that it is binding on China as a principle of customary international law.

\subsection{Public Participation as a Treaty Obligation}

Here we look at the provisions on public participation in international environmental law treaties to which China is a party and which have a bearing on China's obligations in the governance of its freshwater resources.

As will be demonstrated below, most of the provisions on public participation are of such an abstract and ambiguous nature that they may be considered nebulous and even, arguably in some cases, meaningless. But, as we shall see, not all provisions are alike. Some treaties are quite soft on public participation - only encouraging it in a general sense-while others are much more substantive-obligating States to facilitate a particular kind of public participation.

\subsubsection{Public Participation as an Obligation of Result}

Sometimes a treaty obliges States-including China — to involve the public in water governance. This may be considered an obligation of result: ${ }^{20}$ when the public is not consulted, this fact may in itself already constitute a breach of the treaty and, thus, a wrongful act, unless the State can invoke the existence of circumstances precluding wrongfulness.

When a treaty prescribes public participation in domestic decision-making procedures, it can do so in a wide variety of ways. The State may be obligated to involve the public in conducting an Environmental Impact Assessment (EIA), preparing a national action programme (NAP), initiating a project under the Clean Development Mechanism of the Kyoto Protocol ${ }^{21}$ or engaging in other kinds of activity. The State may be obligated to inform the public of these

19 Examples of treaties referring to this principle are listed in Jonas EBBESSON, 'Principle 10: Public Participation' in Jorge E VIÑUALES, The Rio Declaration on Environment and Development: A Commentary (OUP 2014) 287.

20 An obligation of result requires the State to ensure the establishment/maintenance of a particular situation—a specific result. See further Rüdiger WOLFRUM, 'Obligation of Result Versus Obligation of Conduct: Some Thoughts about the Implementation of International Obligations', Mahnoush H. ARSANJANI, Jacob COGAN, Robert SLOANE and Siegfried WIESSNER (eds), Looking to the Future (Brill 2010) 364. 
activities, or even to involve the public in their drafting, through consultation, notification and sharing of information.

It is not always clear what precisely States are required to do with such input in the decision-making process. For instance, although the Convention on Biological Diversity states that public participation ought to be facilitated in 'procedures requiring environmental impact assessment of the party's proposed projects, ${ }^{22}$ it is not clear exactly who forms part of 'the public' in the procedures, how such an EIA should eventually influence the State's decision to carry out a particular project and to what extent the input of public participation must play a role. ${ }^{23}$

Similarly, the Memorandum of Understanding on Environmental Principles Governing the Tumen River Economic Development Area states that 'the Contracting Parties will consult with ... and provide opportunities for involvement by the affected citizens and interested NGOS at appropriate stages of the development and environmental planning processes for the Region. ${ }^{24}$ Among all the treaties relating to China's transboundary waters, this Memorandum contains the most specific provision on the obligation of facilitating public participation. However, what these 'appropriate stages' are and what the impact might be of such involvement on the decision-making process is not further elaborated.

According to the Convention to Combat Desertification, ${ }^{25}$ national action programmes (NAPs) must be developed and implemented through 'participatory mechanisms, ${ }^{26}$ to be employed at all decision-making stages and levels of the NAP. One of the issues in the framework of the United Nations Convention to Combat Desertification is water scarcity and sustainable water governance. 'Effective participation' should be provided for 'at the local, national and regional levels of NGOs and local populations ... in policy planning, decision

22 Convention on Biological Diversity (5 June 1992) 1760 UNTS 79, art 14(1)(a).

23 On the link between the Convention on Biological Diversity and water governance, see e.g. Sabine BRELS, David COATES and Flavia LOURES, Transboundary Water Resources Management: the role of international watercourse agreements in implementation of the CBD (CBD Technical Series No 40 2008) <https://www.cbd.int/doc/publications/cbd-ts -40-en.pdf $>$ accessed 23 April 2018.

24 Memorandum of Understanding on Environmental Principles Governing the Tumen River Economic Development Area and Northeast Asia (12 June 1995), art 2(4).

25 The United Nations Convention to Combat Desertification in those Countries Experiencing Serious Drought and/or Desertification, Particularly in Africa (14 October 1994) 1954 UNTS 3 ('Convention to Combat Desertification') has rather specific provisions on participation in relation to Asia, addressed in the section immediately below.

26 Kyle W DANISH, 'International Environmental Law and the "Bottom-up" Approach: A review of the Desertification Convention' (1995) 3(1) Indiana Journal of Global Legal Studies 151. 
making, and implementation and review of national action programmes. ${ }^{27} \mathrm{The}$ purported effect of such participation is, however, not detailed in the treaty.

The next example relates to climate change mitigation and participation in the promotion of a Clean Development Mechanism (CDM). Here, the State has an obligation to 'help participants who are interested in identifying and designing the projects. ${ }^{28}$ Nonetheless, to what extent the participants are able to influence the formulation of the projects, as autonomous agents, is unclear.

Finally, compared with the general nature and ambiguity of the majority of the provisions on public participation, the Cartagena Protocol on Biosafety is a little more specific, at least on the type of participation that is required. It obliges States to undertake public consultation in the decision-making process regarding living modified organisms. ${ }^{29}$

\subsubsection{Public Participation as an Obligation of Conduct}

Public participation can also take the form of an obligation of conduct imposed on nations. An obligation of conduct consists of a standard of conduct or behaviour that requires a well-governed State to 'endeavour to reach the result set out in the obligation, ${ }^{30}$ as part of a process of due diligence. The State must have provided the possibility and it must have done its best to implement public participation. Here too, the exact type, intended participants and timing of the participation is often left obscure.

For example, in Article 6(a)(iii) of the UNFCCC, the parties commit to promote and facilitate 'public participation at national, as appropriate, subregional and regional levels in addressing climate change and its effects and developing adequate responses. ${ }^{31}$ Without fixed programmes on combating

27 Convention to Combat Desertification (n 25) art 1o(2)(f).

28 Agreement between the Government of the French Republic and the Government of the People's Republic of China concerning the promotion of a Clean Development Mechanism (CDM) as provided for in article 12 of the Kyoto Protocol to the United Nations Framework Convention on Climate Change, art 4.

29 Cartagena Protocol on Biosafety to the Convention on Biological Diversity (29 January 2000) 2226 UnTS 208 ('Cartagena Protocol on Biosafety'), art 23(2).

30 More details of due diligence can be found in Pierre-Marie DUPUY, 'Soft Law and the International Law of the Environment' (1990) 12(2) Michigan Journal of International Law 434; Timo KOIVUROVA, 'Due diligence' in Rüdiger WOLFRUM et al (eds), Max Planck Encyclopaedia of Public International Law (OU 2010), para 8.

31 United Nations Framework Convention on Climate Change (9 May 1992) 1771 UNTS 107 ('UNFCCC'), art 6(a)(iii). See also art 4(1)(i), where the parties shall [p]romote and cooperate in education, training and public awareness related to climate change and encourage the widest participation in this process, including that of non-governmental organizations.' 
climate change, this provision can function in various ways. ${ }^{32}$ The link between combating climate change and sustainable water governance is often made. ${ }^{33}$

Similarly, the obligation in the Stockholm Convention on Persistent Organic Pollutants contains a general obligation on all States parties to promote and facilitate "[p]ublic participation in addressing persistent organic pollutants and their health and environmental effects and in developing adequate responses, including opportunities for providing input at the national level regarding implementation of this Convention. ${ }^{34}$ The treaty does not specify when in the process the public is encouraged to intervene, which particular issues its interventions may address and what the legal consequences of such participation - or lack thereof - are expected to be. If the pollutants flow into a transboundary river, then the environments of all States sharing the river are potentially affected. In such a case, the Convention does not clarify if the stakeholders, either domestic and foreign, can help to address the effects. ${ }^{35}$

Of course, an obligation of conduct is more than a mere recommendation. States cannot simply decide not to do their best to facilitate and promote public participation. At the same time, it must be acknowledged that the success with which these public participation provisions are implemented in essence depends on a State's capacity to do so.

32 Svitlana KRAVCHENKO, 'Procedural Rights as a Crucial Tool to Combat Climate Change' (2010) 38(3) Georgia Journal of International \& Comparative Law 638.

33 See e.g. UN Water, 'Climate Change Adaptation: The Pivotal Role of Water' (UN Water, 6 May 2010) <http://www.unwater.org > accessed 23 April 2018; Adaptation to Climate Change Team (АСт), Background Report: Climate Change Adaptation and Water Governance (4 October 2011) <http://act-adapt.org/wp-content/uploads/2011/o6/og11-Water-Background-Report-WEB.pdf> accessed 23 April 2018; Juan Carlos SANCHEZ and Joshua ROBERTS (eds), 'Transboundary Water Governance: Adaptation to Climate Change' (IUCN Environmental Policy and Law Paper No 75, 2014) <https://portals.iucn .org/library/sites/library/files/documents/iucn-eplp-no.o75.pdf> accessed 23 April 2018.

34 Stockholm Convention on Persistent Organic Pollutants (22 May 2001) 2256 UNTS 119 ('Stockholm Convention'), art 10 (1)(d).

35 The relevance of the Stockholm Convention to water should be clear: 'in order to accomplish the convention's objective of eliminating, restricting, preventing accumulation, and accomplishing sound waste management to protect human health and the environment, it is necessary to keep [Persistent Organic Pollutants] out of freshwater bodies, including international watercourses.' UN Environment Programme (UNEP), Freshwater Law and Governance: Global and Regional Perspectives for Sustainability (March 2014) $75<\mathrm{http://}$ wedocs.unep.org> accessed 23 April 2018. 


\subsubsection{Public Participation as a Recommendation}

In contrast to the obligation of conduct, sometimes a treaty only requires States to 'involve' the public. A range of such recommendations can be identified. For example, with regard to National Action Programmes (NAPs) the Regional Implementation Annex for Asia of the Convention to Combat Desertification, states: '[I]n preparing and implementing national action programmes, the affected country Parties of the region ... may ... involve affected populations, including local communities, in the elaboration, coordination and implementation of their action programmes'36 and 'evaluate, with the participation of affected populations, past and current programmes for combating desertification and mitigating the effects of drought, in order to design a strategy and elaborate activities in their action programmes. ${ }^{37}$ Further, they 'may 'prepare technical and financial programmes. ${ }^{38}$ The use of the discretionary 'may' indicates the recommendatory character of these provisions. The function of public participation is unspecified as to how it should back up either the design or the implementation of NAPs, let alone the establishment of NAPs themselves. ${ }^{39}$

In a bilateral treaty on environmental cooperation, China and New Zealand agreed to cooperate, among other things, on 'the improvement of environmental awareness, including environmental education and public participation.40 To this end, the instrument provides that each party 'may, as appropriate, invite participation of other organisations in identifying potential areas for cooperation and in undertaking cooperative activities. ${ }^{41}$ When organisations accept an invitation, it is not clear what form the participation will take and what consequences it will have.

Finally, the Rotterdam Convention on Hazardous Chemicals contains perhaps one of the most modest and unimposing invitations to encourage public participation. It allows States to draw upon 'technical expertise from any relevant source. ${ }^{42}$ Although less apparent, the technical expertise of any

36 Convention to Combat Desertification (n 25) Annex II Regional Implementation Annex for Asia, art 4(1)(b) (emphasis added).

37 Ibid art 4(1)(d).

38 Ibid art 4(1)(e) (emphasis added).

39 Jonas EBBESSON, 'The Notion of Public Participation in International Environmental Law' (1998) Yearbook of International Environmental Law 51, 84-85.

40 Environment Cooperation Agreement between New Zealand and China (4 April 2008) 2592 UNTS 207.

41 Ibid art 2(4) (emphasis added).

42 Convention on the Prior Informed Consent Procedure for Certain Hazardous Chemicals and Pesticides in International Trade (1o September 1998) 2244 UNTs 337 ('Rotterdam Convention'), art 6(1). 
relevant source, we argue, could be provided by members - experts—of the public, perhaps even at their own initiative. On the link between the Rotterdam Convention on Hazardous Chemicals and water governance, a recent UNEP report notes that the Rotterdam Convention 'provides governments with the legal and monitoring tools to control the substances entering watercourses in order to protect public health and the environment.'43

\subsubsection{Preliminary Conclusion}

The above analysis raises the question of why the rules and regulations calling for public participation are generally so vague. The answer could be that the vague and ambiguous nature of the provisions on public participation in the treaties which have a bearing on the exploitation and management of freshwater resources allows a significant degree of national discretion. The lack of clarity may make these provisions acceptable to a wider range of States, and thus make it more likely that countries such as China, that do not have strong traditions of formal public participation, are more willing to become parties. It leaves room for States to adapt public participation mechanisms to their own traditions and practices of policy and public administration. On the other hand, where facilitating public participation is merely recommended, the State can simply decide not to facilitate it at all, without any particular legal or political consequences. Further, where a State is urged to make a serious effort at facilitating public participation (obligation of conduct), the result can be that, in the end, the public is not involved at all where this proves to be too onerous or cumbersome for the State to facilitate.

Even where public participation is perceived as obligatory, the vaguenessof the type of participation to be used, of the intended participants, and of the impact the public's input must have on the decision-making process - still leaves much for the State to fill in.

It could be argued that more clearly defined international commitments on public participation might be better enforced in practice. If that is the case, it is regrettable that these treaty provisions are generally so vague.

This raises the question of how States actually make use of their interpretative freedom and the ensuing discretion of implementation. Of particular interest for our purposes is how China has understood its obligations to facilitate

43 Unep, Good Practices for Regulating Wastewater Treatment: Legislations, Policies and Standards (2015) 27 <http://wedocs.unep.org/handle/20.500.11822/10737> accessed 23 April 2018. 
public participation and how it has implemented these in practice. This is the focus of the next section.

\subsection{China's Implementation of International Provisions on Public Participation}

China's implementation of the abovementioned treaty obligations on public participation is examined in two ways. First, we discuss China's understanding or legal interpretation of these provisions, as reflected in its relevant national goals and plans. Second, we look at the way in which the Chinese authorities have actually implemented these provisions in practice, as reflected in compliance reports. ${ }^{44}$

It is not possible to provide detailed analysis of China's implementation of all of the treaty provisions mentioned above, as not all China's relevant implementation and compliance reports are shared with the public. In particular, we found little documentary evidence of implementation of bilateral agreements. However, we found a sufficient number of documents to examine the interpretation and implementation of six multilateral treaties. These documents include the country's general reports on freshwater and related environmental issues as well as ad hoc reports on some specific treaties that cover the matter of public participation.

We witnessed a paradoxical phenomenon in China's implementation of the public participation provisions to which it has committed itself. One would expect that the more demanding the international obligations are, the more detailed and imposing the national implementation will be, so as to remain consistent with the standard as set at the international level. However, on the contrary, our research has shown that the treaty with the strongest public participation obligations has the weakest domestic action plans at China's national level and vice versa.

Of course, there is a difference between ambitions expressed in national action plans and actual participation on the ground. It must be acknowledged that actual public participation in decision-making processes is still in its infancy in China, especially when compared with the recent accomplishments in enhancing public awareness. It could be argued that the former automatically follows the latter and that we need to be patient, as these developments take time. Indeed, the focus of the policy-makers has slowly moved from calling on

44 Since these two overlap and interact at different levels, the two ways are not analysed separately, but they are taken together in this section. The focus is on the former, as it is beyond the scope of this article to uncover the facts on the ground in China. 
the public to 'be aware,' to calling on the public to 'be participants.' This is a big leap, both for the policymakers and for the public itself. Thus far, most participatory mechanisms have not yet been able to exert much actual influence on decision-making processes and there is thus still a long way to go.

\subsubsection{Public Participation in China as an Obligation of Result}

If we look, for example, at the relatively robust public participation provisions in the Biological Diversity Convention, we see that the Chinese 'translation' into domestic policies is rather modest. A priority mentioned in the (2008) National Report from China is to 'enhance public participation and increase public awareness of conservation', with an emphasis on the training of professionals and on school and university education.' ${ }^{45}$ This is a significant watering down of the obligation to provide the public with an opportunity to participate in the conduct of an EIA, 'as appropriate' under Article 14(a) of the Convention on Biological Diversity. ${ }^{46}$ Despite noting the significance of public engagement in the implementation of biodiversity policies in a general sense-which must in itself be applauded - the Chinese State plan has not actually dealt with it in the particular context of the EIA. There is no direct mention of participation by communities in EIA processes concerning biodiversity conservation. Instead, its focus is on ensuring 'a better understanding of the importance of biodiversity and of the Convention' through more public awareness, and by emphasizing the importance of participation by 'indigenous and local communities' in particular in the implementation of the treaty. ${ }^{47}$ Looking at implementation on the ground, we see that the report is somewhat general and vague in its evaluation. It merely mentions that 'the ability and enthusiasm of public participation has been greatly improved' and that progress made was mostly in the realm of enhancing public awareness. ${ }^{48}$

With regard to the implementation of the Convention to Combat Desertification (UNCCD), China's track record is somewhat paradoxical. We found little mention of public participation as an objective in the relevant

45 Ministry of Environmental Protection, 'China's Fourth National Report on Implementation of the Convention on Biological Diversity' (November 2008) iv and $75<$ https://www.cbd .int/doc/world/cn/cn-nr-04-en.pdf> accessed 23 April 2018.

46 Art 14(a) reads: 'Introduce appropriate procedures requiring environmental impact assessment of its proposed projects that are likely to have significant adverse effects on biological diversity with a view to avoiding or minimizing such effects and, where appropriate. allow for public participation in such procedures'.

47 For the Cartagena Protocol on Biosafety, facilitating public awareness, education and participation has been mentioned in Ministry of Environmental Protection (n 45) 75.

Ibid $27-8$ and 75 . 
national action plans, despite the fact that the Convention's obligations on public participation are relatively strong. However, with regard to implementation on the ground, some interesting statements can be identified in China's National Report on Implementation of the UNCCD. The setting up of 'a whole society participating in combating desertification system' 49 is heralded, as well as NAPs which 'encapsulated the intelligence of NGOS and other relevant societies. ${ }^{50}$ On their face, these are impressive accomplishments.

\subsubsection{Public Participation in China as an Obligation of Conduct}

Let us now turn to the second category of treaty provisions on public participation: those that contain an obligation of conduct. The Chinese national plan for implementation of the Stockholm Convention on Organic Pollutants puts an emphasis on encouraging the general public to take part in decision-making processes, exactly as the Convention itself prescribes. This is done, inter alia, by establishing 'incentive mechanisms' for such participation. ${ }^{51}$ The Chinese authorities also value 'the participation of environmental analysis laboratories' in monitoring, and appreciate the function of 'hearings to promote public participation in decision making' and 'in Convention implementation activities'; and they value the role of NGOs in 'promotion and oversight relating to POPs [Persistent Organic Pollutants] hazards. ${ }^{.52}$ The intention to be an active facilitator of public participation that the Chinese State Plan indicates is firmly in line with the Convention.

Taking another example, the UNFCCC: the Chinese authorities made it an objective 'to establish an action mechanism for response to climate change involving a wide range of enterprise and public participation' by $2010 .{ }^{53}$ This objective was to be achieved with the help of two more specific measures: first the setting up of an 'incentive mechanism' and then through 'public supervision. ${ }^{54}$ These measures were also put in place in response to calls from Chinese civil society, encouraging the government to stimulate the public and NGOs to participate in policy-making processes and to monitor implementation processes

49 China National Report on the Implementation of the United Nation's Convention to Combat Desertification 2006, 49 .

5o Ibid 24. See also Melvin WOODHOUSE, 'Is Public Participation a Rule of the Law of International Watercourses?' (2003) 43(1) Natural Resources Journal 137, 169.

$5^{1}$ The People's Republic of China, 'National Implementation Plan for the Stockholm Convention on Persistent Organic Pollutants' (April 2007) 89 and 98.

$5^{2}$ Ibid 113, 128-129.

53 National Development and Reform Commission, The People's Republic of China, 'China's National Climate Change Programme' (June 2007) 29 <http://en.ndrc.gov.cn/newsrelease/ 200706/Po20070604561191006823.pdf > 2 accessed 23 April 2018.

Ibid. 
on climate change. ${ }^{55}$ Again, this is in accordance with the Convention's appeal to parties to make a serious effort at facilitating public participation. ${ }^{56}$

A Chinese report on implementation of the UNFCCC's provisions on public participation refers to the establishment of a 'management system and working mechanism' built to address it, featuring 'wide participation of various localities and industries. ${ }^{57}$ This sounds promising, but there is no specification of how the stakeholders have influenced the workings of the mechanism. ${ }^{58}$ In addition, the Chinese Centre for China Climate Change Communication has produced 'a statistical analysis of Chinese people's awareness of climate change, its influence, and how to tackle it, and their support for relevant policies, and their participation in remedial actions.' They have also produced 'reference material for Chinese policy makers. ${ }^{59}$ All this is laudable, but it refers more to raising awareness than to efforts at actually allowing the public to have an influence on the decision making itself.

\subsubsection{Public Participation in China as a Recommendation}

The Rotterdam Convention was, as explained above, rather modest on public participation. Nonetheless, this modest call to stir up public participation has been taken up with remarkable enthusiasm by the Chinese authorities. In particular, suggestions have been made to engage 'all chemical stakeholders, and especially the wide participation of the chemical industry,' as this was seen as 'the basis for successful implementation of state environmental policies for the sound management of chemicals.' ${ }^{60}$ For this reason, an ambition was expressed to 'establish public participation mechanisms' providing stakeholders

55 Chinese Civil Society Coalition on Climate Change, 'Chinese Civil Society on Climate Change: Consensus and Strategies' (November 2009) 19 <https://www.eu-china.net/up loads/tx_news/23_Chinese_Civil_Society_on_Climate_Change_o1.pdf> accessed 30 April 2018.

$56 \quad$ UnFCCC (n 31$)$ art 6(a)(iii).

57 Information Office of the State Council the People's Republic of China, 'China's Policies and Actions for Addressing Climate Change' (November 2011), <http://english.gov.cn/ archive/white_paper/2014/og/og/content_281474986284685.htm> accessed 1 May 2018.

58 Ibid.

59 The National Development and Reform Commission, 'China's Policies and Actions for Addressing Climate Change' (2012) <https://digital.library.unt.edu/ark:/67531/ metadc501479/m2/1/high_res_d/China's\%2oPolicies\%2oand\%2oActions\%2ofor\%20 Addressing\%20Climate\%20Change\%202012.pdf> accessed 30 April 2018.

6o China Council for International Cooperation on Environment and Development, 'Major Issues and Policy Framework for Environmentally Sound and Strategic Management of Chemicals in China' (November 2017) <http://environmental-partnership.org/wpcontent/uploads/download-folder/2007_Report_on_Environmentally-sound\%20and_ Strategic_Management_of_Chemicals_in_China_EN.pdf> accessed 30 April 2018. 
'a platform' in decision making. ${ }^{61}$ The actual practice might be reason to curtail our optimism. A recent implementation report refers to the lack of voluntary public participation in 'the safe management of chemicals' and corresponding 'safety and environmental protection decision-making,' which is apparently due to the fact that 'the competent departments favour command and control license management system and methods of registration management.' ${ }^{62}$

\subsection{Preliminary Conclusion}

In this section, we looked at references to public participation in environmental law treaties to which China is a party, and which have some bearing on China's freshwater governance in relation to both internal and transboundary waters. Three categories of provisions were distinguished:

- those that oblige States to include public participation in decision-making processes (obligation of result);

- those that urge States to do their best to include public participation in decision-making processes (obligation of conduct); and

- those that recommend States to include public participation in decisionmaking processes (recommendations).

We saw that with all three kinds, the provisions on public participation were very vague, ambiguous and of a general nature. This allows the State a significant degree of leeway and flexibility in the implementation. In other words, they leave much discretional space for the national rule makers and law administrators to play with.

We then turned to the Chinese approach concerning the interpretation and implementation of these treaty obligations from the point of public participation. From the national plans and reports on implementation performance, we concluded that enhancing public participation has been incorporated as a general objective in the implementation of basically all abovementioned treaties. Yet we detected a significant variety in the strategies and details of design. On implementation on the ground, we concluded that there is still much work to be done. The reports we studied fail to explain how much influence public participation processes have had on the actual decision-making procedures. Another noticeable fact is that the focus is generally on raising public awareness, not so much on encouraging the public to actually influence the decision making. This is the key difference between China and the international perceptions of the role of public participation. We suggest that a synthesis of these approaches might prove to be the next step in the process. Our study

\footnotetext{
$61 \quad$ Ibid.

62 Ibid 3 and 29 .
} 
of public participation was limited to the analysis of specific reports. In other words, we limited ourselves to desk research. Clearly it would be useful to analyse the actual functioning of these public participation mechanisms on the ground through empirical research projects, but that was beyond the scope and methodology of this particular study.

We believe that China is on the right track to fulfil its treaty obligations with regard to public participation, even if there is room for improvement. We will finish this section with some general remarks which might help to move things forward. Firstly, it would help if the various treaty provisions referred to above could be more explicit on what States are expected to do. It is difficult to interpret these watered-down compromises in some of the treaties as a reflection of the same public participation principles included in, for example, the Aarhus Convention or Principle 10 of the Rio Convention. ${ }^{63}$ To improve the design of the treaties, attention should be paid to the basic elements of public participation. If these international provisions only require States to make public participation possible in a general sense, without indicating which members of the public are supposed to participate, in what way and with what results, then the temptation for States to stick to the weaker types of public participation is too strong. International treaty provisions should also be more specific about the nature of the responsibility.

Second, we believe that the intentions, as expressed in the Chinese State plans, generally provide a faithful and earnest attempt at translating the treaty obligations into national policies. The challenge now lies in implementation and more robust monitoring thereof. It is, of course, well known that China is struggling to control the use of its freshwater resources, so there is still a long way to go. ${ }^{64}$

Third and finally, we witness a general shift in China from emphasising public awareness to encouraging what other jurisdictions pursue: actual public involvement in real decision-making procedures. We find this shift very promising. However, such a shift is not accomplished overnight, especially if

63 Jonas EBBESSON, 'Public Participation' in Daniel BODANSKY, Jutta BRUNNÉE and Ellen HEY (eds), The Oxford Handbook of International Environmental Law (OUP 2007) 699.

64 There are many articles in the newspapers on issues relating to water pollution in China. See e.g. 'China's groundwater plagued by pollution' China Daily (19 November 2014) <http:// www.chinadaily.com.cn/china/2014-11/19/content_18942169.htm> accessed 23 April 2018; Cecilia TORTAJADA, 'Clean water vital for the economic growth' China Daily (13 April 2015) <http://www.chinadaily.com.cn/opinion/2015-03/24/content_19889168.htm> accessed 23 April 2018; 'E China chemical spill forces water cut-off' China Daily (18 May 2014) <http://www.chinadaily.com.cn/china/2014-05/18/content_17515930.htm> accessed 23 April 2018. 
the peculiarities of the Chinese political system are appreciated, including its top-down governance model, and its preference for centralised control at national level and decentralised administrative control at regional level. ${ }^{65}$ It cannot come as a surprise that the adaptation period, in which some progress is already observable, needs long-term endeavours and patience.

\section{Public Participation in China's Water Law}

\subsection{Introduction}

In the previous section, we looked at how China has implemented specific provisions in international agreements relating to public participation in its domestic law and policy which relate in some way to freshwater management. In this section, we look at public participation in China's water governance more broadly. We look at public participation in China's water law, as well as examining public participation obligations in China's environmental law which have a bearing on the governance of China's freshwater resources.

Before commencing our analysis, it may be helpful to set out the methodology and the sources we have used in this part of our research. China's law is rather complex. At the top, we find the Constitution of 1982, last amended in March 2018. This Constitution says little to nothing about public participation in water governance. Under the Constitution are: the laws, promulgated by the National People's Congress (NPC), administrative regulations, promulgated by the State Council; local regulations promulgated by the local People's Congress; and administrative rules including local and departmental rules.

We also refer to the Five-Year Plans (FYPs), prepared by the Central Committee of the Communist Party of China. These plans reflect the Communist Party's ruling ideology and establish social and economic development blueprints for the society. They are not legal documents but they do set binding targets.

When it comes to institutional management, the Ministry of Ecology and Environment (MEE) (formerly the Ministry of Environmental Protection) of the People's Republic of China, until recently, was the focal point for the management of questions related to water pollution, while the Ministry of Water Resources, with the help of its seven river basin commissions, is responsible for water resource management. We thus also look at ministerial regulations made by these two ministries.

65 Chenggang XU, 'The Fundamental Institutions of China's Reforms and Development' (2011) 49(4) Journal of Economic Literature 1076, 1082. 
Based on the above, we first examine the two most recent FYPs. Then we look at the relevant laws, national administrative regulations and ministerial regulations. We have chosen to discuss these provisions in this order because the FYPs set out the general strategy. The Party's political discourse is then translated by the NPC into concrete laws and regulations, and the administrative agencies—-the State Council—make the laws and regulations operational by formulating the supporting rules and measures.

\subsection{FYPs and Public Policies}

The 11th FYP (2006-2010) stipulated that the public should 'be encouraged to supervise the environmental protection activities and participate. ${ }^{\prime 66}$ The 11th FYP has been considered to be a turning point in China's environmental protection policies, since it set up binding targets for environmental protection (in its sub-plans) for the first time in China's history. The binding targets in FYPs are formulated in clear terms and with specific deadlines, which are further assigned to the local government. The expected outcomes are usually detailed and precise. In other words, attaining these goals can be considered an obligation of result incumbent upon local governments. The targets which are not binding in the Plans are usually taken as mere recommendations. ${ }^{67}$

The above-mentioned principle of public participation in the 11tth FYP is to be understood as a mere recommendation, since the consequence of the failure to attain the goal of public participation, as determined by the Plan, is not specific and verifiable. The Plan calls for 'improving the scientific and democratic decision-making mechanism, and the collective decision making on major issues, expert advice, public notices and hearings, and decision making accountability system ... protecting the citizens right of access to information, participation, expression and supervision on governmental work' 68

The 12th FYP (2011-2015) strengthens environmental protection by adding more binding targets but without making any substantial improvements on public participation, the statement of which is similar to the 11th FYP. The

66 NPC，'中华人民共和国国民经济和社会发展第十一个五年规划纲要' [The eleventh five-year plan outline for the national economy and social development of the People's Republic of China] (14 March 2016) <http://www.gov.cn/gongbao/content/2006/ content_268766.htm> accessed 30 April 2018 ('11th FYP'), chapter 24.

67 Liping DAI, 'A new perspective on water governance in China: Captain of the River' (2015) 40(1) Water International 87.

68 NPC, 11th FYP (n 66) chapter 30. 
relevant departments are urged to listen to public opinion, through public hearings, when formulating environmental standards. ${ }^{69}$

Within the period of the 11th and 12th FYPs, the State Council issued many Opinions, three of which are closely related to environmental protection. ${ }^{70}$ The main function of the opinions is to provide guidance to the related ministries and local governments on the construction of environmental protection mechanisms in both general and specific fields. Some binding environmental targets are laid down by the latter two Opinions. For example, the Opinion on the Implementation of the Most Stringent Water Resources Management prescribes that 'the total amount of water consumption shall be controlled within 700 cubic meters by 2030.71 Similarly, the Opinion on Accelerating the Development of Ecological Civilization states that 'the forest cover rate shall reach $23 \%$ above by $2020 .{ }^{72}$

However, when looking for traces of public participation in these three opinions, we find that the principle of public participation is only generally touched upon but not highlighted. For example, the Opinion on Strengthening Major Environmental Protection Work only mentioned that 'the procedure of the EIA should be open and transparent, and the input from the public should be fully solicited. ${ }^{73}$ The Opinion on the Implementation of the Most Stringent Water Resources Management suggested that 'scientific and democratic decision making should be promoted and the public participation mechanisms should be improved by listening to the public opinions and enhancing the transparency in the process of decision making. ${ }^{74}$ The Opinion on Accelerating the

69 NPC, ‘中华人民共和国国民经济和社会发展第十二个五年规划纲要’ [The Twelfth Five-Year Plan Outline for the National Economic and Social Development of the People's Republic of China] (16 March 2011) <http://www.gov.cn/2011h/content_1825838_10.htm> accessed 30 April 2018 ('12th FYP'), chapter 40.

70 These are the Opinion on Strengthening Major Environmental Protection Work, the Opinion on the Implementation of the Most Stringent Water Resources Management and the Opinion on Accelerating the Development of Ecological Civilization.

71 State Council, ‘国务院关于实行最严格水资源管理制度的意见' [Opinions on the Implementation of the Most Stringent Water Resources Management], No. 3 (12 January 2012) <http://www.gov.cn/zwgk/2012-02/16/content_2067664.htm> accessed 30 April 2018.

72 Central Committee of the Communist Party of China and the State Council, '中共 中央国务院关于加快推进生态文明建设的意见' [Opinions on Accelerating the Development of Ecological Civilization] (25 April 2015) <http://www.xinhuanet.com/ politics/2015-05/05/c_1115187518.htm> accessed 30 April 2018.

73 State Council, “国务院关于加强环境保护重点工作的意见' [Opinions on Strengthening Major Environmental Protection Work], No. 35 (17 October 2011) <http:// www.gov.cn/zwgk/2011-10/20/content_1974306.htm> accessed 30 April 2018.

74 State Council, Opinions on the Implementation of the Most Stringent Water Resources Management ( $\mathrm{n} 71)$. 
Development of Ecological Civilization did not add much in terms of strengthening public participation. Public participation is not listed as one of its main goals, but only addressed as a component of the development of ecological civilization. The Opinion urges national and local governments to 'improve their public participation system, disclose environmental information [in a timely manner], protect the environmental rights of the public, strengthen the systems of reporting, public hearing and public supervision, and promote citizen involvement. 75

Based on the above analysis, we conclude that facilitating public participation is mainly regarded as something that is recommended but not strictly and legally required in any circumstances in the FYPs and their supporting regulations.

\subsection{Laws}

Laws are promulgated by the Standing Committee of the National People's Congress. The Environmental Protection Law 2014 identifies public participation as one of its basic principles. It includes a whole chapter on the prescription of 'information disclosure and public participation'-albeit with a focus on information disclosure. ${ }^{76}$ Disclosure of information is, of course, only a prerequisite for public participation. It does not empower citizens or allow them to be involved in the process of decision making itself. Pursuant to the definition of public participation proposed at the beginning of this article, we do not consider disclosure of information as a form of public participation as such; it should be regarded merely as a prerequisite to public participation.

Laws related to environmental protection, under the umbrella of the Environmental Protection Law can be further divided into three categories based on their functions: pollution prevention and control laws, resource conservation and utilization laws, and environmental management laws. All three categories have some link with the governance of freshwater resources since they present different elements of environmental governance, i.e. pollution prevention and control, resource conservation and utilization, and general management.

Many of the laws in the first group - pollution prevention and controltouch upon public participation. For example, the Air Pollution Prevention and Control Law requires that, 'while making or revising the air environmental

75 Central Committee of the Communist Party of China and the State Council (n 72).

76 NPC, ‘中华人民共和国环境保护法’ [Environmental Protection Law of the People's Republic of China] (1989, revised in 2014) <http://www.lawinfochina.com/display.aspx? id $=18126 \&$ lib=law\&SearchKeyword $>$ accessed 30 April 2018, chapter 5 . 
quality standards and the air pollutants emission standards, the opinions of ... the general public shall be solicited.77 The Water Pollution Prevention and Control Law prescribes that 'all units and individuals shall have ... the right to supervise any act that pollutes or damages the water environment and to inform against the polluter. ${ }^{78}$ The Law on the Prevention and Control of Environmental Pollution by Solid Waste and the Law on Prevention and Control of Radioactive Pollution also proclaim the same right. However, none of them provide further indications as to how this right ought to be put into effect in practice.

As with the laws of the first group, in the laws in the second categoryresource conservation and utilization laws - the principle of public participation is only touched upon in very general terms. For example, the Water and Soil Conservation Law requires that 'while making water and soil conservation plans, the opinions of experts and the general public shall be solicited. 79 Similarly, the Renewable Energy Law states that 'when developing a plan for the development and utilization of renewable energy resources, ... the department responsible for developing the plan shall solicit comments from relevant entities, experts and the general public.' 80 Other laws in this group, including the Water Law 2016, the Agricultural Law 2012, the Forest Law 2009, the Mineral Resource Law 2009 and the Marine Environmental Protection Law 2017, do not refer to the principle.

The last category of laws includes those that relate to environmental management. The EIA Law is actually the only one such legal instrument thus far. ${ }^{81}$ Consistent with many other jurisdictions, the EIA Law makes public participation a required component of the process of environmental assessment.

77 NPC, ‘中华人民共和国大气污染防治法” [Air Pollution and Prevention Law of the People's Republic of China] (1987, amended in 1995, revised in 2000 and 2015) <http:// news.xinhuanet.com/legal/2015-08/30/c_128180129.htm> accessed 30 April 2018, art 10.

78 NPC, ‘中华人民共和国水污染防治法’ [Water Pollution Prevention and Control Law of the People's Republic of China] (1984, amended in 1996, revised in 2008) <http://www .lawinfochina.com/display.aspx?id=6722\&lib=law\&SearchKeyword $>$ accessed 30 April 2018, art 10.

79 NPC, ‘中华人民共和国水土保持法' [Water and Soil Conservation Law of the People’s Republic of China] (1991, revised in 2010) <http://www.lawinfochina.com/display.aspx?id $=8524 \&$ lib $=$ law \&SearchKeyword $>$ accessed 30 April 2018, art 13.

80 NPC, ‘中华人民共和国可再生能源法' [Renewable Energy Law of the People’s Republic of China], issued by the NPC in 2005, amended in 2009, <http://www.lawinfochina.com/ display.aspx?id=8828\&lib=law\&SearchKeyword $>$ accessed 30 April 2018, art 9.

81 NPC, ‘中华人民共和国环境影响评价法'[Environmental Impact Assessment Law of the People's Republic of China] (2002, amended in 2016)<http://www.lawinfochina.com/ display.aspx?lib=law\&id=2496\&CGid $>$ accessed 30 April 2018. 
It requires that 'the State encourages relevant entities, experts and the general public to participate in the appraisal of the environmental impacts in appropriate ways. ${ }^{\prime 2}$ The EIA Law requires an EIA only for governmental plans and construction projects. ${ }^{83}$ Governmental plans can relate to land use and regional, watershed and sea areas development, as well as plans for industry, agriculture, energy, transportation, urban construction, tourism, and natural resource development. For governmental plans, the public participation rule is as follows:

In case a program may cause unfavourable environmental impact or directly involve the environmental interests of the general public, the body that decides the special plans shall, prior to submitting the draft of the programs for examination and approval, seek the opinions of the relevant entities, experts and the general public ... by holding demonstration meetings or hearings or by any other means, except [when] it is provided by the state that it shall be kept confidential. ${ }^{84}$

In the case of construction projects, the exact obligation depends on the 'seriousness' of the potential environmental impacts the project is anticipated to have. When a construction project has a 'significant' potential environmental impact, the developers must prepare a fully-fledged EIA report. When a project is anticipated to have a 'light' potential environmental impact, the developers are only required to fill in an environmental impact report form. For projects with a 'very small' environmental impact, developers need only submit an environmental impact registration form. ${ }^{85}$ Only those projects with a 'significant' potential environmental impact require public participation. In such cases, the construction entity 'shall, before submitting the construction project for examination and approval, seek the opinions of relevant entities, experts and the general public by holding demonstration meetings, hearings or by any other means.' ${ }^{\prime 6}$ Therefore, although public participation is compulsory in the EIA Law, the scope of application is very limited.

\footnotetext{
$82 \quad$ Ibid art 5 .

83 Ibid.

84 Ibid art 11. The term 'special program/plan' refers to a plan specially made for a specific issue area, such as industry, agriculture, energy, water conservation, etc. A 'general plan' is for social and economic development.

85 Ibid art 16 .

86 Ibid art 21.
} 


\subsection{National Administrative Regulations}

The national administrative regulations are issued by the State Council. There are two different categories of regulations. ${ }^{87}$ We will analyse those relating to public participation.

The first category of regulations encompasses the general administrative regulations, which are aimed at managing governmental action. For example, the Regulation on Disclosure of Government Information was enacted, among others, 'for the purpose of safeguarding the legal access to government information by citizens, legal persons and other organizations [and] improving the transparency of government work.' ${ }^{88}$ It provides supporting methods to implement the principle of public participation by regulating the scope of disclosure of the governmental information, as well as the methods, the procedure, the monitoring, and the safeguarding methods. In terms of scope, the regulation addressed voluntary information disclosure by the government and application by the public for information disclosure.

Another category of regulations includes those that can be subsequently adopted by the NPC as laws. These regulations share common characteristics with laws and provide only general rules on the principle of public participation. For example, the Regulation on Nature Reserves states that 'all units and individuals shall have ... the right to [be] inform[ed] ... or lodge complaints [against] the units or individuals who damage the nature reserves. ${ }^{\prime 89}$

\subsection{Ministerial Regulations}

Ministerial Regulations are issued by the ministerial-level departments within their competence. We focus on the regulations of the MEE, as environmental protection and water pollution prevention in China is the responsibility of that Ministry. They must develop national environmental protection policies and plans, thereby taking the lead in environmental water governance.

Pursuant to the EIA Law which came into force in 2003, the Ministry issued the Interim Measures for Hearing the Administrative License in Respect of Environmental Protection (2004) to regulate administrative licenses in the

87 NPC, ‘中华人民共和国立法法’ [Legislation Law of the People's Republic of China] (2000, amended in 2015) accessed 30 April 2018, art 65 .

88 State Council, ‘中华人民共和国政府信息公开条例’ [Regulation on Disclosure of Government Information of the People's Republic of China] (5 April 2007) <http:// en.pkulaw.cn/display.aspx?cgid=90387\&lib=law $>$ accessed 30 April 2018, art 1.

89 State Council, ‘中华人民共和国自然保护区条例’ [Regulation on Nature Reserves of the People's Republic of China] (10 September 1994, revised on 8January 2011) <http://www .lawinfochina.com/display.aspx?id=12164\&lib=law\&SearchKeyword $>$ accessed 30 April 2018, art 7 . 
field of environmental protection. ${ }^{90}$ These Interim Measures prescribe the conditions for public hearings. They stipulate that:

the administrative department that organizes a public hearing shall abide by the principle of openness, fairness, impartiality and convenience-forpeople, fully hear the opinions from citizens, legal persons and other organizations, and guarantee their respective rights to state their respective opinions, to cross-examine, and to defend themselves. ${ }^{91}$

The scope of the hearing includes the implementation of administrative licenses in respect of environmental protection, the construction projects that may have serious impacts on the residents' living environmental quality and the special planning which may have a negative influence upon the environment and directly affect the environmental interests of the public. The Interim Measures define the rights and the duties of the organizers and participants to the public consultations, the procedures, the safeguarding measures and the standard forms to be used at the hearings.

Another regulation, the Interim Measures for Public Participation on Environmental Impact Assessment, ${ }^{92}$ prescribes similar principles to those applied in the administrative license stated above. Again, it is stated that public participation shall be 'open, fair, extensive and convenient-for-public.'93 The Measures state that, 'after the information disclosure, the public shall be solicited via surveys, consultations, seminars, debates, or hearings. ${ }^{94}$

Most recently, the MEE enacted Measures for Public Participation in Environmental Protection (2015), ${ }^{95}$ for the purpose of 'safeguarding the legal rights of citizens, legal persons, and other organizations to obtain environmental

9o State Environmental Protection Administration, “环境保护行政许可听证暂行办法” [Interim Measures for Hearing the Administrative License in Respect of Environmental Protection] (1 July 2004) <http://www.lawinfochina.com/display.aspx ?lib=law\&id $=3608 \&$ CGid $>$ accessed 30 April 2018.

$91 \quad$ Ibid art 4.

92 State Environmental Protection Administration, 环境影响评价公众参与暂行办 法' [Interim Measures for Public Participation on Environmental Impact Assessment] (14 February 2006, <http://baike.baidu.com/view/516278.htm > accessed 30 April 2018.

93 Ibid art 4.

$94 \quad$ Ibid art 12.

95 Ministry of Environmental Protection, “环境保护公众参与办法” [Measures for Public Participation in Environmental Protection] (13July 2015) <http://www.lawinfochina.com/ display.aspx?id=19634\&lib=law\&SearchKeyword $=\&$ SearchCKeyword $>$ accessed 30 April 2018. 
information, supervise and participate in environmental protection. ${ }^{96}$ The Measures indicate that 'the environmental protection departments can solicit the opinions and suggestions of citizens, legal persons and other organizations on relevant environmental protection matters or activities through solicitation of opinions, questionnaire surveys, holding of symposia, expert demonstration meetings, or hearings or by any other means. ${ }^{97}$ The Measures also describe the procedures for soliciting the public input for the $\mathrm{MEE}$ and other environmental protection departments.

These Measures are detailed and progressive, but they are also limited to a very specific context, such as the preparation of EIA reports, which is not always required whenever the State in activities related to freshwater management and exploitation.

\subsection{Preliminary Conclusion}

In conclusion to this section, we can say that a variety of laws provide that the public has the legal right to participate in certain environmental activities. However, the measures to realize such rights, which ought to be addressed by the administrative regulations or the ministerial regulations, are often lacking. While there are very detailed measures on public participation in some ministerial regulations, they apply only in specific contexts.

\section{4}

\section{Conclusion}

This article has addressed a central question: what is the role and current status of public participation in China's water governance?

We first looked at international agreements relating to water governance to which China is a party. We found that only a few of such agreements referred explicitly to public participation, and these were mostly agreements that only had an indirect bearing on transboundary water governance. In our view, those international treaty provisions that $d o$ deal with public participation are too general to provide any guidance on the type of participation that was required. This makes it too easy for States to ratify such treaties and then set in place very weak and largely symbolic measures on public participation.

Nevertheless, when looking at China's implementation record, we noted that the treaty provisions with the strongest public participation obligations actually were often those which lack implementation, while the less demanding

96 Ibid art 1.

97 Ibid art 4 . 
international law provisions led sometimes to more impressive implementation efforts. While this particular finding might be partly coincidental, it does at least show that relatively strong provisions on public participation in a treaty do not necessarily encourage States-China in particular-to create strong public participation mechanisms at the domestic level. It could be that strong provisions provide for less flexibility in implementation and thus hinder the type of efforts they seek to promote. But there might very well be other factors at play here, unrelated to the content of the public participation provision in the treaty. It could be that some issues lend themselves better to public participation than others. Further research is required to analyse what (other) factors trigger the Chinese authorities to opt for strong or weak public participation mechanisms.

We then looked at China's own domestic water governance more generally. There too, we encountered many provisions which were relatively general. They left many questions unanswered. We found that China's domestic law is generally not sufficiently clear about what type of public participation is called for, and which 'public' should be invited to participate. In fact, it is not always clear whether the Chinese national authorities are committed to guaranteeing public participation, or to doing their best to facilitate it, or whether they simply let local authorities decide what level of public participation is appropriate. Clearly, more empirical research is needed to shed further light on the actual implementation practice of China's public participation obligations both under international and domestic law. 